\section{Lab closure sparks fears that US prion research is waning}

Helen Pearson, New York

A major lab dedicated to studying prions closed down last week, causing some to worry about the future of research on these proteins in the United States. But at the same time, another US lab revealed findings emphasizing the importance of prions in brain-wasting diseases.

The Laboratory of Central Nervous System Studies at the National Institute of Neurological Disorders and Stroke (NINDS) in Bethesda, Maryland, has long conducted research on prions. These are the infectious agents thought to cause conditions such as mad cow disease and its human version, variant Creutzfeldt-Jakob disease.

Work at NINDS has been winding down for some years and came to a halt on 30 July with the retirement of its medical director Paul Brown. The closure leaves the National Institutes of Health (NIH) with just one major in-house prion research facility, at Rocky Mountain Laboratories in Hamilton, Montana.

"The idea of losing the whole NINDS facility is devastating," says virologist Dean Cliver of the University of California, Davis, who has advised government agencies on prion-research strategy. The closure reflects the lack of interest in prion research in the United States, he adds.

Bruce Chesebro, who heads the prion lab at Rocky Mountain, says that NIH labs with secure, long-term funding are important for prion research because animals take months or years to develop symptoms. Last November, the Institute of Medicine also recommended that the NIH should strengthen its in-house prion research.

A handful of other US labs study prions, including Stanley Prusiner's facility at the University of California, San Francisco. Prusiner won a Nobel prize in 1997 for his work in identifying prions as a disease-causing agent. This week, he and his group announced that they had created a prion protein in bacteria and shown that it caused disease when injected into the brains of mice (G. Legname et al. Science 305, 673-676; 2004), strengthening the hypothesis that prions cause disease without the help of genetic material.

US scientists acknowledge the quality of such work, but say they need more labs to keep up with the pace of research in Europe. The NINDS is considering recruiting another lab in the field, says Eugene Major, acting director of the institute's neuroscience programme.

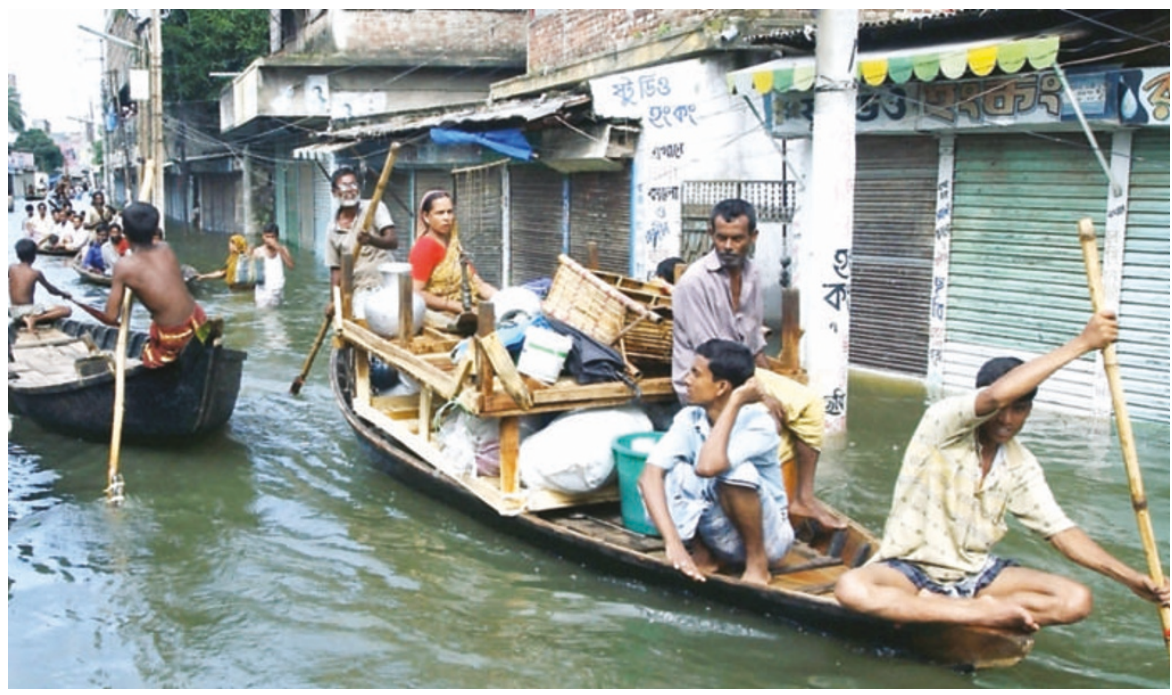

Muddy waters: scientists are striving to clarify the issues as Bangladesh is hit by devastating floods.

\title{
Reform of land use urged as floodwaters rise across Asia
}

David Cyranoski, Tokyo

Storms and floods ravaging Asia this summer have claimed the lives of more than 1,500 people and left tens of millions facing food shortages and water-borne diseases. While relief agencies are busy sending aid, scientists are working out how to prevent such disasters from happening again.

Several factors have conspired to make the floods in the northeastern region of Bangladesh the worst in recorded history, says Atiq Rahman, head of the Bangladesh Centre for Advanced Studies in Dhaka. Four flash floods came in quick succession, he says, and unusually high tides have slowed the water's discharge into the sea. Little can be done about such conditions, but we can act to lessen their impact, he says.

The Dhaka-based Flood Forecasting and Warning Center, for example, can give three to seven days' notice of floods. This time could be used to focus relief efforts, says Rahman, allowing emergency supplies to get to the right areas of the country. "We knew which areas would be affected most. There was enough warning," he says, adding that better political organization was all that was needed.

Changes to land use could also have a big effect, says Vaidyanatha Subramanian, a hydrogeochemist at Jawaharlal Nehru University in New Delhi. Canals in Bangladesh have been squeezed by land development, he says, increasing the chance that they will burst from their confines. River banks have been eroded by unregulated mining for sand and by bathing at religious festivals. Subramanian is now collecting data about the timing, strength and duration of rains and the resulting river flow, to work out how much of the flooding is caused by nature rather than humans.
In Taiwan, where typhoon Mindulle caused particularly bad floods in early July, scientific experts have visited disaster sites to work out what went wrong. They note that much of the problem was beyond the government's control: the rains were particularly heavy and the 1999 Chi-Chi earthquake left loose soil that was easily swept away. But they also identified the farming of tea and betelnuts on steep slopes as a factor in excessive soil erosion. The government's subsequent decision to shut down three farming areas has provoked tension with local people.

Bangladesh must also cope with social tension over its land use. Some of the richer areas near hard-hit Dhaka were kept dry by massive embankments. Reports say police used rubber bullets to break up protests where angry citizens tried to break open sluice gates in attempts to open natural drainage routes for the water.

Some of Bangladesh's woes are being addressed by a National Water Management Plan, approved by the National Water Research Council this March. The plan aims to decentralize decision-making about flood management, and create a central organization for sharing information. But the projects, to be implemented over 25 years, have had little time to take effect, says Rahman.

As of 2 August, water levels had dropped to normal throughout most of Bangladesh. But that is little comfort, says Rahman. More rain, expected in mid-August, will create havoc in the saturated area. "The next round will be worse," he says.

For more news and analysis go to news@nature.com www.nature.com/news 